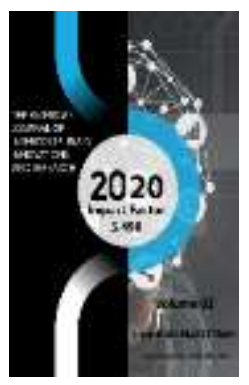

\title{
Ceremonies And Actions Performed By The Population At The Pilgrimage
}

Sanabar Djuraeva

Candidate Of Historical Sciences, Doctoral Student (Dsc) National University Of Uzbekistan

Journal Website: http://usajournalshub.c om/index,php/tajiir

Copyright: Original content from this work may be used under the terms of the creative commons attributes 4.0 licence.

\section{ABSTRACT}

This article mentions that after the introduction of the Islamic religion in Central Asia, ancient religious customs became Islamic, and these rituals and act were held for centuries by the population. Based on the places of pilgrimage of the Surkhandarya region, a scientific analysis was conducted.

\section{KEYWORDS}

Customs, rituals, acts, holy, pilgrimage, scientist, miracle worker.

\section{INTRODUCTION}

Visiting the holy shrines has become a tradition in the social and spiritual life of Central Asia, its historical roots go back a long way. In ancient times, the people who lived in this region, along with the imaginary mastery of the mysteries of nature, the harmony in it, gradually formed in them religious ideas.
During the Neolithic period (new stone, 6-4 thousand years $B C$ ), views related to the sacred animal, statues dedicated to the mother goddess, various religious ceremonies and rites of worship appeared [16:34]. From that time on, people thought that certain things, objects, stones, trees, caves, springs had supernatural qualities.In Zoroastrianism, too, four elements: 
earth, water, fire, and air are considered sacred. Much emphasis has also been placed on the strength of faith and belief [3: 112-113]. Even today, the peoples of Central Asia consider it a sin to pollute the soil, water, fire and air. Some of the traditions associated with fire in this religion have survived to the present day.

\section{THE MAIN RESULTS AND FINDINGS}

After the introduction of Islam in our country, local traditions and values merged with "Arab culture" and took on an Islamic character. During this period, Imam Bukhari, Isa Termezi, Hakim Termezi, Najmiddin Kubro, Bahauddin Naqshband, Burhaniddin Marghinoni, Khoja Alouddin Attar, Sufi Alloyar and other scholars who were famous in the Islamic world in Central Asia emerged.

Mausoleums were built by kingdoms, khanates and principalities on the burial places of great people and turned into sacred shrines. In some places, if their footsteps were reached, or from their graves, soil was brought and graves were made. The locals considered such places sacred and visited them. At the same time, springs, trees, hills and caves created by nature were also considered sacred places.

The concept of "sacred" has been used in all religions to refer to what is most precious to human beings. In Islam, Mecca and Medina, in Shiites, the cities of Karbala and Najaf are common holy places and are visited. In the Hindus, the Ganges, the city of Jerusalem is considered sacred to Jews and Christians [6: 335].

One of the traditions that has emerged within the framework of Islam is the rituals and ceremonies performed by the people in the holy shrines. It is an ancient custom among our people to go to the shrines of great saints and ask God for their intentions by visiting them.

Our Prophet Muhammad (SAAS) said, "Whoever wants to visit the graves, let him visit. Because visiting the grave reminds us of the Hereafter "[9: 6]. Remembering the Hereafter, on the other hand, keeps one away from evil and brings one closer to goodness.

Hakim Termezi (IX-X centuries), buried in the shrine in Old Termez, was a high-ranking mystic and Sharia scholar, the seventh representative of the 12 Sufi series up to the XI century. This people is called Hakimiya [1:19]. Because he is a Sufi, the people value his shrine. Among the population this place is called "Termez ota".

The mausoleum where his body was buried is now a huge shrine in the Muslim world, which is visited by many pilgrims from the Arab world, various regions of the republic, districts of our region. The fact that pilgrims from our country are asked, "Did you visit Imam Bukhari, Hakim Termezi, Isa Termezi before you came here?" Shows how high the prestige of these scholars is in the Islamic world.

People who come to the shrine of Hakim Termezi recite the Qur'an about the scholar. By sacrificing in this place, they make a donation to the way of God and feel relieved as if they are free from all evil feelings. The following can be mentioned in the conduct of sacrificial ceremonies in shrines. Sacrifice in Arabic means "to draw near to God," that is, to sacrifice one's life for the sake of God in order to receive His mercy and intercession [6: 619]. The famous geographer and traveler Ibn Battuta said in his Travelogue that "in Central Asia, the slaughter of animals (horses, sheep, oxen) for sacrifice in the tombs of saints was a custom of both the pagans and the Muslims, as well as the Mongols" [5:54]. It is clear from this that the custom of offering sacrifices in shrines was not unique to Muslims.

There is a tree at the back of Hakim Termezi's mausoleum, and pilgrims tie ropes to it, intending to do so. By tying a rope, the pilgrim demonstrates hope and confidence in the sanctuary. When his wish came true, he came a second time, untied the rope he had tied, and 
sacrificed in the way of God. This is typical of the people of Central Asia, including the Kazakhs. Ch.Ch. Valikhanov writes: "All the unusual views of nature, the branches of trees growing in the desert, the magnificent plant were also considered sacred and served as a place of pilgrimage. Each passenger tied a piece of a shirt or a piece of cloth and sacrificed an animal. " [2:56]

The mausoleum of Qirq Qiz (Forty Girls) (IX-XIV centuries) in Termez district is a well-known archeological monument in the republic. It is also a sacred shrine revered by the people. The peoples of Central Asia have long had a tradition of asking for help from the "Forty Girls". This habit was later preserved in fortunetelling women. The text written by ethnographer O.A.Sukhareva also contains the fortune-teller's appeal to forty virgins [11: 115].

One of such shrines is "Qirq Qiz" (Chil Dukhtaron) shrine at the foot of Koyi Safet (White Mountain) on top of Khoja Asmin village of Khanjiza mountain of Uzun district of Surkhandarya region. The mountain is so named because it looks white and there is always snow on top. There are forty spruces between the mountains. There is also a Shakar Seb (Sugar Apple) spring [12:44]. Views on springs mean that they form the basis of the ecology of life.

It should be noted that the number "Forty" played an important role in the legends about the Forty Girls. Almost all scholars confirm that the veneration of the number "forty" dates back to ancient times in the Turkish people. This number goes back to pre-Islamic traditions. Most importantly, the deification of numbers, belief in his prophecy, and the appointment of various ceremonies and events with him were common, especially in Central Asia. Over time, this "magic" number became part of Islamic rules, and various ceremonies were performed around this number.
The large number of pilgrims coming to Qadamjah was due to the fact that the person lying there had a great status in the Islamic world, as well as the prophecies he made while he was alive. "When Ibn Battuta narrates about a saint in the cities he visited, he certainly describes his prophecies with confidence (it was customary in the land of Morocco, where Ibn Battuta was born and raised, to honor the saints)" [5:54].

In the village of Katta Vakhshivor, Altynsay district, Surkhandarya region, there is a shrine of the poet and thinker, saint Sufi Olloyar (1644-1721), who created a unique school as a continuation of the traditions of Uzbek classical literature and mysticism (XVII-XVIII centuries) [13: 31-32].

The people know Sufi Alloyar as a prophetic saint. It is said that by his prophecy, two springs appeared in the village of Big Vakhshivor. One of them is Kotirbulak and the other is Karabulak. The water of the scab comes out six months a year, dries for six months, and cures skin diseases [8: 131]. The population still drinks water from these springs. Pilgrims from Switzerland, Arabia, Afghanistan, different regions of the country and districts of the region visit the shrine.

Khoja Alouddin Attor (14th century), a follower of the Naqshbandi sect and a mystic, lived in Denau district. He was appointed head of the Movarounnahr scholars during the reign of Amir Temur. Amir Sayyid Sharif Juzjani (Ali ibn Muhammad ibn Ali, 1330-1414) and Mawlana Nizam ad-Din are the pir of the Khomush [14:11].

Hoja Alouddin is the 17th saint in the Attor series. His grave is now in the cemetery of Sheikh Alouddin Wali or Astana Buva in Denau. During his lifetime, he said, "Whoever loves me, let him sit on my doorstep." There are also the graves of his descendants in the cemetery: his sons Sheikh Hassan Attar Wali and Hoja Yusuf Attar [7:16]. 
The shrine of Hoja Alouddin Attor is wellknown in the Arab states, our republic and regions. An important aspect of the shrine is that there are five footprints near the tomb of Alouddin Attor. It is said that a visitor's claw is enough to match his footprint. Some religious scholars have said that the panja is a sign of solidarity between our Prophet (saas) and his four righteous chaharis.

In the village of Ak-Astana bobo on the left bank of the Surkhandarya River (Uzun district of Surkhandarya region) is the shrine of AkAstana bobo (IX-X centuries) named after Abu Hurayra (602-679), one of the famous Companions, narrators and faqihs [14:24] . Kadamjo is known as an archeological monument and is visited by many pilgrims from different districts of the province along with the locals mainly on Wednesdays of the week. An important aspect of the shrine is that the main pilgrims are those who are not busy, unhappy girls, those who ask God for children.

The girls take a broom and sweep the mausoleum. In the tales and legends of the Turkic peoples, sweeping the threshold of the royal palace means that the queen came as a gift, sweeping the sacred tombs means asking for help from Allah through the saints [4: 164]. In the Uzbek and Tajik peoples, when a groom goes to a house, he sweeps the threshold of the house with his skirt in good faith [10: 227].

In special places at the shrine on Wednesdays, women hold a Bibi Mushkulkushod for unhappy girls who are not working.

According to mythological notions, the image of a woman who saves a man from trouble. (Bibi Mushkulkushod Persian - "a woman who makes things easy"). According to one legend, an old man who was collecting firewood lost his sickle and in search of it. He entered the cave where Bibi Mushkulkushod lived. Bibi Mushkulkushod tells the old man that if he held a feast in his name every Wednesday of the week, his sickle would be found and he would gather more firewood than he does now. The old man complies with this request and goes about his business [6:106].

In Islam, this custom is a heresy and a ritual that has survived among the people from previous religions. Nowadays, some women consider holding Bibi Mushkulkushod as a donation to the cause of God so that the work can go on.

The shrine of Ak-Astana Baba is the shrine of Abu Hurayra, and the people appreciate the spirit of the Companions. From there they receive spiritual nourishment, physical strength, and the life of the Companions is an example for them.

People who go to the shrine feel relieved of their spiritual pain because they have sincerely prayed to God because of their feelings. Opinions regarding the rituals of the shrine in Islam have a centuries-old history. It is known that the rituals performed at the shrines have been practiced for a long time. This is manifested primarily in the mental state of the pilgrims.

During the years of independence, the preservation of material and spiritual monuments, the restoration of religious and national values have risen to the level of state policy. PD-4947 of the President of the Republic of Uzbekistan dated February 7, 2017 "On action strategy for further development of the Republic of Uzbekistan", PD-5328 of February 3, 2018 "On additional measures to create favorable conditions for the development of tourism potential of the Republic of Uzbekistan" On the basis of the Decree of the Cabinet of Ministers of the Republic of Uzbekistan № 709 of April 16, 2018 "On measures to radically improve the activities of the field of religious enlightenment" № PD-5416. According to him, the Public Charitable Foundation "Vaqf" was established. This fund is responsible for the preservation, repair, beautification of historical and architectural shrines in our country, 
mosques, shrines, imam-khatibs, imamdeputies, mutawallis, muezzins, material and social support, salaries, religious enlightenment of our ancestors who made a great contribution to the development of Islam. The task was set to publish his works, to further enhance the prestige of the shrines and shrines in the Muslim world in our country, to create conditions for the attraction of local and foreign pilgrims to the shrines. At present, 189 shrines and shrines across the country are attached to the charity foundation "Vaqf" on the basis of a contract of free use.

\section{CONCLUSION}

In conclusion, it can be said that the shrines, mausoleums, shrines, religious and national values in our country are among them. The practices in these areas also have their own national, religious, psychological and historical roots. The main idea in the views of the population regarding the shrines is the concept of sincerity. Therefore, a sincere visit to the grave is the main criterion of the pilgrimage. This is evident in every ceremony and act of the pilgrimage. Deep study of them on a scientific basis will contribute to the rise of spiritual life in our country, the elimination of some negative habits among the people, the formation of positive qualities and traditions. To study the life, activity, history of shrines, traditions of the shrines, to pass them on to the younger generation as our spiritual heritage, to form in their minds a healthy faith, a correct worldview, to increase the status of shrines in the Muslim world. Attracting local and foreign pilgrims there, developing pilgrimage tourism is one of the urgent tasks before us.

\section{REFERENCES}

1. Abdullaev A. Life, work and teachings of Hakim at-Termizi // Al-Hakim at-Termizi and his period and: Proceedings of the International Scientific Conference. Termez: Termez State University, 2004.
2. Abramzon S.M. Subjects of Kazakh, Kyrgyz and Karakalpak cult // Material culture and economy of the peoples of the Caucasus, Central Asia and Kazakhstan. - L .: Nauka, 1978.

3. Askarov A. History of Uzbekistan. - T .: Teacher, 1994.

4. Bosilov V.N. Legend: Verit ili ne verit? // Soviet ethnography. - Moscow: 1974 №1.

5. Ibrohimov N. Ibn Battuta and his journey to Central Asia. - T .: Sharq bayozi, 1993.

6. Islamic encyclopedia. - T $\therefore$ National Encyclopedia of Uzbekistan, 2017.

7. Mamanazarov A. Sattorov B. Denov pearl. $\mathrm{T}$.: Literary Fund of the Writers' Union of Uzbekistan, 2001.

8. Menqul Xanjar. Vakhshivor and Sufi Olloyar. - Termez: Jayxun, 1993.

9. Mirzo Ahmad Khushnazar. Etiquette of visiting the cemetery. - T .: Movarounnahr, 2005.

10. Monogarova L.D. Semya i semeynyy byt // Etnograficheskie ocherki Uzbekskogo selskogo naseleniya. - M .: Nauka, 1969.

11. Murodov O. Shomanskiy obryadovby folklor u tadjikov sredney chasti doliny Zeravshana // Domusulmanskie verovaniya i obryadb v Sredney Azii. - M .: Nauka, 1975.

12. Muhammad Yusuf. Disappointed Khandizagiy. Tacholloi love. - Dushanbe, 2003.

13. Pardaev O. Oltinsoy shrines. My hometown. - T .: Writer, 2003.

14. Pugachenkova T.A. Ak-Astana baba // Sovetskaya archeologiya. - T .: 1960. № 3.

15. Safarov Sh. Termez and Termez. - Termez: Jayxun, 1993.

16. Ergashev $H$. Hamidov $H$. History of Uzbekistan. - T .: G'afur G'ulom, 2015.

17. Nurmatovna, D. S. (2020, October). Representatives of the" Khojagon" direction of the Naqshbandi sect. In Archive of Conferences (Vol. 7, No. 1, pp. 8-11).

18. Djuraeva, S. (2019). ZORAASTRISM AND ZOOLATRIC VIEWS AT THE MONUMENT JARQOTAN WHICH SITUATES AT THE 
SOUTH UZBEKISTAN. Theoretical \& Applied Science, (9), 166-168.

19. Djuraeva, S. (2019). SACRED PLACES IN SURKHAN OASIS AND POPULATION'S RELIGIOUS LIFE. Theoretical \& Applied Science, (7), 125-130.

20. Nurmatovna, D. S. (2020, October). Representatives of the" Khojagon" direction of the Naqshbandi sect. In Archive of Conferences (Vol. 7, No. 1, pp. 8-11).

21. Omonov, Q., \& Karimov, N. (2020). Importance of Ancestoral Heritage. The American Journal of Social Science and Education Innovations, 2(09), 196-202.

22. Karimov, N. R. (2020). A True Successor of Great Central Asian Scholars. Journal «Bulletin Social-Economic and Humanitarian Research,(7), 62-69.

23. Djuraeva, S. (2020). THE ROLE OF SPIRITUAL AND MATERIAL HERITAGE OF SURKHANDARYA REGION IN THE DEVELOPMENT OF TOURISM. Solid State Technology, 63(6), 290-296.

24. Kariev, A., \& Aminov, H. (2020). New information about Imam al-Zarnūjī and his work "Ta'lim al-Muta'allim". Solid State Technology, 63(6), 2372-2387.

25. Kurbanazarova N. Sh. (2020). Linguistic Study of some Uzbek Ethnographisms Expressing Wedding Ceremonies. International Journal of Psychosocial Rehabilitation, No.5, Pp. 3735-3740. 